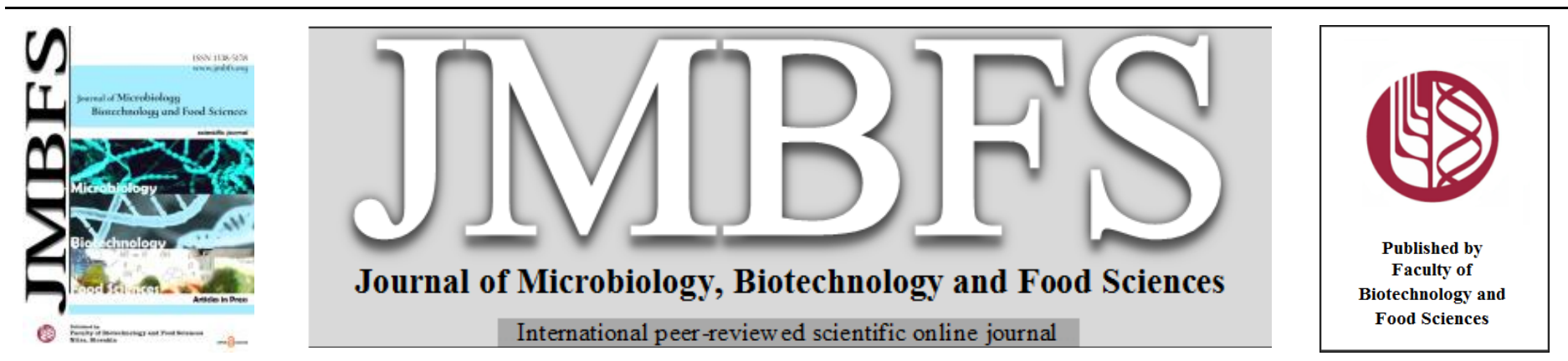

\title{
EFFECT OF PROTEIN AND CARBOHYDRATE COMPONENTS UPON QUALITY PARAMETERS AND VIABLE PROBIOTIC BACTERIA CONTENT IN MILK MIXTURES DURING THEIR DRYING AND STORAGE
}

\author{
Antonina Minorova ${ }^{1}$, Irina Romanchuk ${ }^{2}$, Sergii Verbytskyi*3 ${ }^{3}$ Svitlana Danylenko ${ }^{4}$, Natalya Krushelnytska ${ }^{1}$, Oksana Potemska $^{4}$, Sergiy \\ Narizhnyi ${ }^{5}$
}

\begin{abstract}
$\operatorname{Address(es):~}$
${ }^{1}$ Institute of Food Resources of the National Academy of Agrarian Sciences of Ukraine, Department of Dairy Products and Baby Food, Yevhen Sverstiuk St, 4a, 02002, Kyiv, Ukraine.

${ }^{2}$ Institute of Food Resources of the National Academy of Agrarian Sciences of Ukraine, Deputy Director on Scientific Work, Yevhen Sverstiuk St, 4a, 02002, Kyiv, Ukraine.

${ }^{3}$ Institute of Food Resources of the National Academy of Agrarian Sciences of Ukraine, Department of Informational Support, Standardization and Metrology, Yevhen Sverstiuk St, 4a, 02002, Kyiv, Ukraine.

${ }^{4}$ Institute of Food Resources of the National Academy of Agrarian Sciences of Ukraine, Department of Biotechnology, Yevhen Sverstiuk St, 4a, 02002, Kyiv, Ukraine. ${ }^{5}$ Bila Tserkva National Agrarian University, Faculty of Biotechnology, Department of Food Technologies and Technologies of Animal Products Processing, Soborna Sq, 8/1, 09117, Bila Tserkva, Kyiv Region, Ukraine.
\end{abstract}

*Corresponding author: tk140@ hotmail.com

https://doi.org/10.55251/jmbfs. 3778

\section{ARTICLE INFO}

Received 1. 10. 2020

Revised 22. 1. 2022

Accepted 28. 1.2022

Published 1. 6. 2022

Regular article OPEN $\partial$ ACCESS

\section{ABSTRACT}

Results of studies of dry milk based mixtures for extremal nutrition, obtained by spray drying at various temperatures are presented. Viable cells number, sensorial, physical and chemical parameters are determined. The increase of dry whey protein concentrate (WPC) content from $1 \%$ to $6 \%$ leads to an increase in the protein content in the product from $25 \%$ to $37 \%$. At the same time, the relative rate of dissolution increases by 2.7 times, and the active acidity decreases by $0.16 \mathrm{pH}$ units. It is established that the drying temperature of the mixtures is $130 \pm 2{ }^{\circ} \mathrm{C}$ at the inlet of the drying tower and $60 \pm 2{ }^{\circ} \mathrm{C}$ at the outlet, can be is recommended for maximum preservation of the viability of probiotic microorganisms. Streptococcus thermophilus strain turned out to be the most resistant to elevated drying temperatures in comparison with other strains. It is noted that the introduction of WPC effected the survival of probiotic bacteria to survival during drying and storage positively. The smallest losses of viable microorganisms after drying the product were found in test samples with strains of Streptococcus thermophilus and Enterococcus faecium and addition of WPC to the product formulation, while the number of viable cells decreased by 1.7 times and 2.1 times, respectively. It was shown that during 18 months of storage, a high rate of viable cells was for the Enterococcus faecium strain and the addition of WPC and barley malt extract (BME) to the samples, where the losses were $11.8 \%$ and $11.9 \%$.

Keywords: dry milk mixtures, drying temperatures, probiotic microorganisms, viable cell content, whey protein concentrate, barley-malt extract, rice flour

\section{INTRODUCTION}

It is well known that nutrition is the most important factor in determining the state of human health, connects it with the environment and affects the body's ability to withstand its harmful effects. According to WHO experts, the health of citizens is $50 \%$ dependent on lifestyle. Therefore, nutrition is closely related to our health and longevity (Lukin \& Marenkova, 2016)

Analysis of the nutritional structure of the population of Ukraine at present shows that the diet of an ordinary Ukrainian is characterized by a protein deficiency in the amount of $10 \ldots 26 \%$ of the need (Molchanova \& Suslianok, 2013).

It is possible to eliminate the deficiency of animal protein in the diet by partially replacing it with vegetable proteins, however, provided that the amino acid composition is balanced (Lishchenko, 2003). Combinations of animal and plant protein products based on the principle of supplementing limiting amino acids and eliminating a possible excess of other essential amino acids are of great importance (Klimenko \& Avdieieva, 2001).

In many countries worldwide, research is underway to create combined milk-based products with specified composition and properties (Alekseeva et al., 2017). So over the past several decades, scientists have focused on the study of the composition and properties of dry combined dairy products for special purposes using ingredients of animal and plant origin (Ivkova \& Piliaeva, 2011).

Considering that dry dairy products have a long shelf life, ease of transportation and the possibility of consumption in autonomous living conditions, the development of technology for special-purpose products is now a promising area of research. However, in addition to convenience, the aforementioned products should be products with increased nutritional and biological value, the use of which should provide good nutrition. For this, functional ingredients are included in the composition of the products.

In scientific works, the importance of the development of new biologically valuable ingredients of animal origin, obtained by processing milk whey using membrane technologies, is noted. These are dry whey protein concentrates (WPC) obtained by ultrafiltration of whey with a protein mass fraction of $80 \%$. Adding them as a filler in dry dairy products for special purposes makes it possible to enrich the product with high-grade milk protein and increase its biological value (Gordienko et al., 2008; Minorova et al., 2013; Minorova et al., 2017; Ostroumova \& Galstian, 2007).

Barley-malt extract (BME) and rice flour can be considered as promising and accessible types of functional ingredients of plant origin. BME is a dietetic food product made from sprouted grains of cereals. Research of Yemelianova et al. (1994) showed that BME contains low-molecular proteins with a complete composition of amino acids, easily digestible carbohydrates in the form of maltose, glucose, fructose, a significant amount of macro- and microelements, vitamins, enzymes, phytohormones and a number of other biologically active substances. According to the results of medical and biological research, it has been established that malt extract normalizes metabolic processes, helps to prevent or reduce negative reactions to extreme influences, reduce morbidity, and improve public health (Lukianova et al., 1991).

Another promising ingredient is rice flour, which should be considered as a carbohydrate-protein complex capable of performing not only important technological functions, but also a source of beneficial nutrients. Rice flour can be 
classified as food for children and dietary purposes (Chaudhary et al., 2001; Ivanova, 2004). These ingredients of plant origin have found wide demand in the domestic market. Adding them to the formulations of food products allows not only to increase their nutritional and biological value, but also to significantly reduce their cost.

A new direction in the dairy industry is the development of dry milk products enriched with lactic acid microorganisms (Ivkova \& Piliaeva, 2012a; Burtsev \& Chernobaev, 2010). So, in recent years, dry multicomponent foods with a balanced composition for the nutrition of the special consumers are gaining more and more popularity (Ivkova $\&$ Piliaeva, 2011).

When developing dry products for special purposes, in particular, dry fermented milk products that will be used to feed people in extreme living conditions (army, navy, expeditions, tourism, etc.), it is necessary to take into account that they should be better than their natural counterparts (soured milk, yogurt, sour cream, etc.). The combination of raw materials of animal and plant origin makes it possible to create products of increased nutritional and biological value (Ivkova \& Piliaeva, 2012b).

Dry fermented milk products are among the most complex heterogeneous systems, the features of heat and mass transfer in which are due not only to rheological properties, but also to the influence of a complex of physical, chemical and biochemical transformations that accompany the drying process. Therefore, in the production of these products, an important factor is the choice of optimal drying parameters (Tamim \& Robinson, 2003)

It has been proven by many scientists that spray drying has an advantage over othe methods as the most common and economically viable method for drying dairy products. It consists in the possibility of using lower temperature regimes of the process (the temperature of the product particles in the drying tower does not exceed $60{ }^{\circ} \mathrm{C}$ ) due to the formation of a huge contact surface of the raw materia (up to $200 \mathrm{~m}^{2} / \mathrm{kg}$ ) with the drying agent (air) by spraying (Dobry et al., 2009; Schuck, 2002; Gabites et al., 2010); Wahlberg, 2010; Lipatov, 1978). This makes it possible to obtain a dry powder with almost complete preservation of food and biologically active substances (Mikhaleva \& Popov, 2010).

The influence of different methods of drying milk mixtures enriched with probiotic bacteria on the viability of probiotic bacteria showed that the storage of a freezedried product was accompanied by intensive oxidation of the fat components that were part of the product. Spray-dried products were more shelf-stable against fat oxidation (Shamanova, 1993). When studying the viability of microorganisms of Bifidobacterium sp. and Lactobacillus acidophilus noted that these probiotic bacteria have the ability to survive in the temperature ranges: at the entrance of the drying tower $130-190{ }^{\circ} \mathrm{C}$ and at the outlet $-60-90{ }^{\circ} \mathrm{C}$. However, the extent of survival of different types of probiotic bacteria at different temperature drying regimes is different (Ivkova \& Piliaeva, 2012a; Burtsev \& Chernobaev, 2010; Shamanova, 1993)

The results of the studies carried out in the Department of Dairy Products and Baby Food of the Institute of Food Resources confirmed the feasibility of creating a product of increased biological value, in particular dry multicomponent mixtures by combining animal raw materials (milk, WPC) and vegetable (BME, rice flour) origin (Minorova et al., 2018; Minorova et al., 2020).

Considering that dry milk mixtures are planned to be used in the future as a fermented milk product for special purposes, it was advisable to enrich the product with probiotic bacteria.

Although the chemical composition and properties of dry milk-based products, including special-purpose products, have already been the subject of numerous studies (Ivkova \& Piliaeva, 2011; Ivkova \& Piliaeva, 2012b; Shamanova, 1993; Vega et al., 2005; Kim et al., 2002; Emam-Djomeh \& Yarmand, 2016; Vorobyova et al., 2010; Novokshanova \& Ozhignova, 2012; Rudavska et al., 2002; Rudavska \& Khakhaleva, 2018; Prytulska et al., 2012; Prytulska et al., 2017), they, however, do not fully disclose the approaches to solving the problem. Further research is required to study the resistance of various types of strains of probiotic microorganisms to the effects of temperature drying regimes, to reveal the dependence of the level of preservation of viable microorganisms on the type of carbohydrate and protein components, as well as on the shelf life of a dry fermented milk product for special purposes.

The objective of our study was determination of sensorial, physical and chemical characteristics of dry mixtures, substantiation of the temperature regimes for drying a fermented milk product, investigation of the effect of protein and carbohydrate components on the content of viable microorganisms from spray drying and storage of dry milk multicomponent mixtures.

\section{MATERIAL AND METHODS}

Multicomponent milk mixtures obtained by spray drying with various ammounts of WPC, adding vegetable fillers, probiotic microorganisms and dried at various temperature conditions, were the subject of this research.

The protein content (by mass) was determined according to the standard method (Milk, 2006).

The water content (by mass) in dry products was determined by a routine method, which is based on the property of the product to lose free moisture during drying at a constant temperature $(102 \pm 2)^{\circ} \mathrm{C}$. The arithmetic mean of the results of two parallel measurements of one sample was taken as the final result, the permissible discrepancies between which did not exceed $0.06 \%$.

The ash content (by mass) was determined by the method based on the incineration of 2.8-3.2 $\mathrm{g}$ of dry product at a temperature of $(525 \pm 25){ }^{\circ} \mathrm{C}$. The mass fraction of ash in percent $(\mathrm{x})$ was calculated by the formula:

$$
X=\frac{\left(m_{1}-m_{2}\right)}{m} \cdot 100
$$

where,

$\mathrm{m}_{1}$ is the mass of the crucible with the ash of the product after incineration, $\mathrm{g}$ $\mathrm{m}_{2}$ is the mass of the empty crucible after ignition, $\mathrm{g}$ $\mathrm{m}$ is the mass of the sample of the product, $\mathrm{g}$

100 is the conversion coefficient of grams to percent.

The arithmetic mean of the results of two parallel measurements of one sample was taken as the final result, the permissible discrepancies between which did not exceed $0.1 \%$.

The mass fraction of fat was determined by a standardized acid method based on the separation of fat from dry products under the action of concentrated sulfuric acid and isoamyl alcohol, followed by centrifugation and measurement of the fat volume in the graduated part of the butyrometer. The arithmetic mean of the results of two parallel measurements of one sample was taken as the final result, the allowable discrepancies between which did not exceed $0.5 \%$, provided that the results were within one smallest division of the butyrometer scale.

The content (by mass) of lactose was determined by a standardized iodometric method in a sample of a product weighing $3.0 \mathrm{~g}$. The arithmetic mean of the results of two parallel measurements of one sample was taken as the final result, the permissible discrepancies between which did not exceed $0.2 \%$.

The active acidity of the product was determined by a standardized method, which is based on the use of a potentiometric method for measuring active acidity using a combined electrode with a conical membrane. After establishing the readings of the device, the measurement results were recorded on the scale (display) of a specific measuring instrument. The product $\mathrm{pH}$ was measured using two parallel samples. Calculations were performed to the third decimal place, followed by rounding to the second decimal place. The measurement results were presented as $(X \pm \Delta)$ by $P=0.95$

where,

$\mathrm{X}$ is the final result of measurements of active acidity, $\mathrm{pH}$

$\Delta$ is the indicator of the accuracy of the method - the boundaries in which the absolute error of $\mathrm{pH}$ measurements is located

$\mathrm{P}$ is the confidence level.

The arithmetic mean of the results of two parallel determinations was taken as the final result of measuring the active acidity in dry milk products.

The solubility index was determined in $\mathrm{cm}^{3}$ by a method based on measuring the volume of insoluble sediment in a reconstituted sample of dry whey after centrifugation at a speed of $8000 \mathrm{rpm}$ for $5 \mathrm{~min}$. The arithmetic mean of the results of two parallel measurements of one sample was taken as the final result, the allowable discrepancies between which did not exceed $0.1 \%$.

The relative dissolution rate was determined by a standardized method based on determining the amount of dry matter in percent, passed into solution while stirring the product for 5 seconds at a temperature of $20{ }^{\circ} \mathrm{C} \pm 0.5{ }^{\circ} \mathrm{C}$. The relative dissolution rate (RDR) was determined in percent by the formula:

$$
R D R=\frac{804 \cdot R_{1}}{100-W_{1}}
$$

Where,

$\mathrm{R}_{1}$ is a reading of the refractometer, \%;

$\mathrm{W}_{1}$ is the moisture content in milk powder, $\%$.

The discrepancy between parallel determinations of the relative dissolution rate was no more than $\pm 2 \%$. The arithmetic mean of two parallel determinations was taken as the final result.

Mathematical processing of the results was carried out by methods of statistical analysis and standard methods of Microsoft Excel Software. The study was repeated three times. The results were taken as reliable at $\mathrm{P}<0.05$.

The content of viable lactic acid microorganisms was determined according to (Food, 2016a); Coliform bacteria in accordance with (Milk, 2014); yeast and mold according to (Food, 2016b)

The amount of E. faecium was determined by the plate method on a solid nutrient medium with mannitol. The method is based on the selective ability of $E$. faecium to ferment mannitol and develop on a solid nutrient medium with it. The number of E. faecium was determined by counting the yellowish colonies grown on the selective medium, around which the color of the medium changed from violet to yellow. The amount of E. faecium in $1 \mathrm{~g}(\mathrm{X})$ was calculated by the formula: 


$$
X=n \times 10^{m}
$$

Where,

$\mathrm{n}$ is number of colonies,

$\mathrm{m}$ is dilution.

\section{RESULTS AND DISCUSSION}

On the basis of previous studies, we substantiated the expediency of combining raw materials of animal and vegetable origin in the composition of dry mixtures, the introduction of carbohydrate components into the product formulation, namely, yas and rice flour $[26,27]$.
At this stage of work, under the conditions of the experimental workshop of the Institute of Food Resources of the NAAS, a number of prototypes of dry mixtures were developed on a spray dryer NIRO-ATOMIZER (GEA-Niro, Denmark, Søborg) with the addition of whey protein concentrate with a protein mass fraction of $80 \%$ (Lithuania). Various amounts of WPC were added to liquid mixtures according to the formulation and the product was dried. The sensorial, physical and chemical parameters shown in Table 1 are determined in dry freshly made mixtures.

It was found that the amount of $6 \%$ WPC and the necessity of the simultaneous adding the amount of $2.5 \%$ citric acid salts to this formulation (to ensure the stability of the milk system during heat treatment of the liquid mixture before drying) has a negative effect on the taste characteristics of the product. Sample No. 4 had a pronounced whey taste with a salty aftertaste (Table 1).

$\underline{\text { Table } 1 \text { Sensorial, physical and chemical parameters of dry mixtures }}$

\begin{tabular}{|c|c|c|c|c|c|}
\hline \multirow{3}{*}{ Parameter } & \multirow{3}{*}{$\begin{array}{l}\text { Control } \\
\text { (milk- } \\
\text { carbohydrate } \\
\text { base) }\end{array}$} & \multicolumn{4}{|c|}{ Amount of WPC KSB-80, \% } \\
\hline & & 1.0 & 2.0 & 4.0 & 6.0 \\
\hline & & Sample 1 & Sample 2 & Sample 3 & Sample 4 \\
\hline $\begin{array}{l}\text { Dry matter content (by } \\
\text { mass), } \%\end{array}$ & $96.06 \pm 0.06$ & $96.50 \pm 0.03$ & $96.76 \pm 0.05$ & $96.20 \pm 0.02$ & $97.04 \pm 0.03$ \\
\hline $\begin{array}{l}\text { Lactose content (by mass), } \\
\%\end{array}$ & $45.70 \pm 0.08$ & $44.11 \pm 0.07$ & $42.75 \pm 0.06$ & $38.57 \pm 0.07$ & $35.78 \pm 0.05$ \\
\hline Fat content (by mass), $\%$ & $16.0 \pm 0.5$ & $14.5 \pm 0.5$ & $14.5 \pm 0.5$ & $14.5 \pm 0.5$ & $14.0 \pm 0.5$ \\
\hline Ash content (by mass), $\%$ & $7.80 \pm 0.04$ & $7.35 \pm 0.06$ & $7.98 \pm 0.05$ & $8.64 \pm 0.06$ & $9.11 \pm 0.07$ \\
\hline $\begin{array}{l}\text { Protein content (by mass), } \\
\%\end{array}$ & $25.98 \pm 0.02$ & $29.57 \pm 0.01$ & $30.72 \pm 0.03$ & $33.93 \pm 0.02$ & $37.14 \pm 0.02$ \\
\hline Active acidity, $\mathrm{pH}$ & $6.84 \pm 0.02$ & $7.06 \pm 0.01$ & $7.05 \pm 0.01$ & $7.02 \pm 0.03$ & $7.00 \pm 0.01$ \\
\hline $\begin{array}{l}\text { Solubility index, } \\
\mathrm{cm}^{3} \text { of crude sediment }\end{array}$ & 0.2 & 0.1 & 0.1 & 0.1 & 0.1 \\
\hline \multicolumn{6}{|c|}{ Sensorial parameters } \\
\hline $\begin{array}{l}\text { Appearance and } \\
\text { consistency }\end{array}$ & $\begin{array}{l}\text { Fine powder } \\
\text { with dense } \\
\text { lumps } \\
\end{array}$ & \multicolumn{4}{|c|}{ Fine homogeneous friable powder without lumps } \\
\hline Taste and smell & \multicolumn{2}{|c|}{$\begin{array}{l}\text { Milky, with a barely perceptible } \\
\text { sweetish aftertaste, without foreign } \\
\text { odors }\end{array}$} & $\begin{array}{l}\text { Milky, with a slight } \\
\text { sweetish aftertaste, } \\
\text { without foreign odors }\end{array}$ & $\begin{array}{l}\text { Milky, rich, with a } \\
\text { tangible and } \\
\text { tangible serum } \\
\text { with a smack, no } \\
\text { foreign odors } \\
\end{array}$ & $\begin{array}{l}\text { Milky, rich, sweetish } \\
\text { with a pronounced } \\
\text { whey taste and salty } \\
\text { aftertaste, no foreign } \\
\text { odors }\end{array}$ \\
\hline Color & Cream & Light yellow & Light yellow & Light cream & Light cream \\
\hline
\end{tabular}

Analyzing the obtained physical and chemical parameters of dry mixtures, it can be noted that the introduction of WPC leads to an increase in the protein content in the product from $25 \%$ to $37 \%$ compared to the control. In this case, the ash content in the product increases by 1.2 times and for a sample with a dose of $6 \%$ WPC is $9.11 \%$, which is accompanied by worsening in the taste properties of the specified product.

The positive effect of the introduction of WCP was noted on the solubility of the dry product, in particular on the values of the solubility index (Table 1) and the relative rate of its dissolution. It was found (Fig. 1) that with an increase in the amount of WPC added, the values of the relative dissolution rate increase 2.7 times compared to the control. As for the acidity of the medium of dry mixtures, it was noted that the introduction of WPC reduced the values of active acidity in comparison with the control by $\mathrm{pH} 0.16$.

Therefore, in order to enrich dry mixtures with a protein component, while obtaining the proper taste and physicochemical characteristics of the product, sample 3 of $4 \%$ WPC was selected for further research.

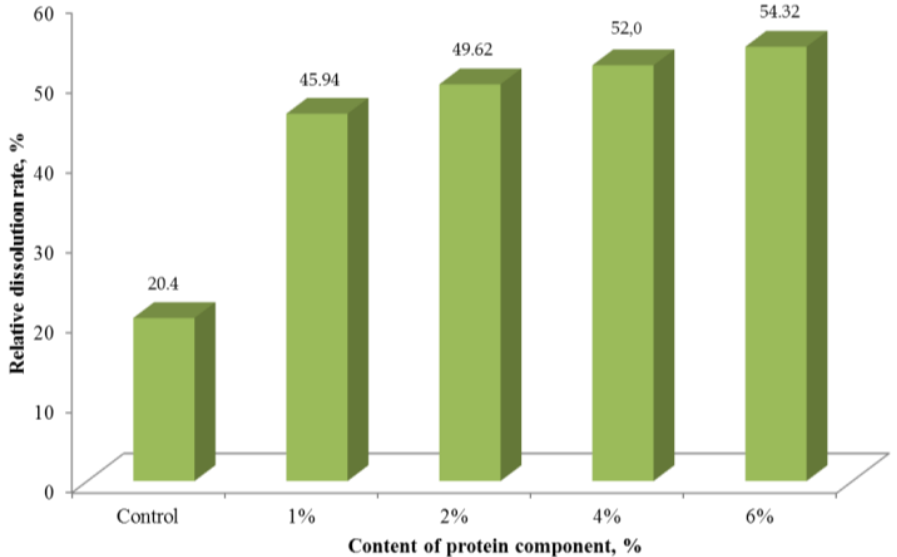

Figure 1 Effect of WPC on relative solubility of dry mixtures

At the next stage of research, we set the task of enriching the dry product with probiotic microorganisms and testing the survival ability of strains of microorganisms Enterococcus faecium, Streptococcus thermophilus and Lactobacillus acidophilus at various temperature regimes for the mixtures being dried. The same amounts $\left(108 \mathrm{CFU} / \mathrm{cm}^{3}\right)$ of probiotic bacteria Enterococcus faecium, Streptococcus thermophilus and Lactobacillus acidophilus activated in skim milk were added to liquid mixtures with a content of solids (by mass) of 17 $20 \%$ before drying under the same conditions, and the ability of bacteria to survive in products at the temperature of spray drying was investigated in the range (130 $150) \pm 2{ }^{\circ} \mathrm{C}$. Moisture in dry products was in the range of $3-7 \%$.

It was established that with an increase in temperature, the number of viable cells of microorganisms of all types decreased. It was recorded (Table 2) that the bacteria of the Streptococcus thermophilus strain in all experimental samples have the 
greatest resistance to survival in the indicated temperature regimes. Somewhat lower values of resistance to survival were noted for the Enterococcus faecium strain. The least resistant strain was Lactobacillus acidophilus, with an increase in drying temperature (Table 2), the number of viable bacteria decreased by 5.8 times. It is known that coccus forms tolerate this processing much better than lactobacilli. It was decided to leave the strains Enterococcus faecium and Streptococcus thermophilus for further research.

When comparing the ability of bacteria to survive during spray drying with various fillers of animal and vegetable origin, WPC was found to be effective. Thus, depending on the increase in drying temperature in samples with WPC, in samples of $S$. thermophilus, their number decreased by 1.7 times, and in samples of $E$.

Table 2 Effect of temperature regimes of drying mixtures on the number of viable cells of microorganisms

\begin{tabular}{|c|c|c|c|c|c|c|c|c|c|}
\hline \multirow{3}{*}{$\frac{\mathscr{O}}{0}$} & \multirow{2}{*}{\multicolumn{2}{|c|}{$\begin{array}{c}\text { Drying } \\
\text { temperature }\end{array}$}} & \multirow{3}{*}{$\begin{array}{c}\text { Amount of } \\
\text { the filler, } \\
\%\end{array}$} & \multicolumn{6}{|c|}{ Species of bacteria and their population, $\mathrm{CFU} / \mathrm{g}$} \\
\hline & & & & \multicolumn{2}{|c|}{ E. faecium } & \multicolumn{2}{|c|}{ S. thermophilus } & \multicolumn{2}{|c|}{ L. acidophilus } \\
\hline & Inlet & Outlet & & $\begin{array}{l}\text { Liquid } \\
\text { mixture }\end{array}$ & $\begin{array}{c}\text { Dry } \\
\text { product }\end{array}$ & $\begin{array}{l}\text { Liquid } \\
\text { mixture }\end{array}$ & Dry product & $\begin{array}{l}\text { Liquid } \\
\text { mixture }\end{array}$ & Dry product \\
\hline & & & BME & & & & & & \\
\hline 1 & $130 \pm 2$ & $60 \pm 2$ & 2 & $3.3 \cdot 10^{8}$ & $9.0 \cdot 10^{8}$ & $3.6 \cdot 10^{8}$ & $19.0 \cdot 10^{8}$ & $0.75 \cdot 10^{8}$ & $0.98 \cdot 10^{8}$ \\
\hline 2 & $140 \pm 2$ & $65 \pm 2$ & $-/ /-$ & $3.3 \cdot 10^{8}$ & $8.2 \cdot 10^{8}$ & $3.3 \cdot 10^{8}$ & $15.0 \cdot 10^{8}$ & $0.70 \cdot 10^{8}$ & $0.74 \cdot 10^{8}$ \\
\hline \multirow[t]{2}{*}{3} & $150 \pm 2$ & $70 \pm 2$ & $-/ /-$ & $3.0 \cdot 10^{8}$ & $3.8 \cdot 10^{8}$ & $3.2 \cdot 10^{8}$ & $8.2 \cdot 10^{8}$ & $0.78 \cdot 10^{8}$ & $0.17 \cdot 10^{8}$ \\
\hline & & & WPC & & & & & & \\
\hline 4 & $130 \pm 2$ & $60 \pm 2$ & 4 & $3.6 \cdot 10^{8}$ & $16.0 \cdot 10^{8}$ & $3.3 \cdot 10^{8}$ & $15.0 \cdot 10^{8}$ & - & - \\
\hline 5 & $140 \pm 2$ & $65 \pm 2$ & $-/ /-$ & $3.4 \cdot 10^{8}$ & $9.2 \cdot 10^{8}$ & $3.7 \cdot 10^{8}$ & $12.0 \cdot 10^{8}$ & - & - \\
\hline \multirow[t]{2}{*}{6} & $150 \pm 2$ & $70 \pm 2$ & $-/ /-$ & $3.2 \cdot 10^{8}$ & $7.6 \cdot 10^{8}$ & $3.0 \cdot 10^{8}$ & $8.7 \cdot 10^{8}$ & - & - \\
\hline & & & Rice flour & & & & & & \\
\hline 7 & $130 \pm 2$ & $60 \pm 2$ & 4 & $3.5 \cdot 10^{8}$ & $5.6 \cdot 10^{8}$ & $3.1 \cdot 10^{8}$ & $11.0 \cdot 10^{8}$ & - & - \\
\hline 8 & $140 \pm 2$ & $65 \pm 2$ & $-/ /-$ & $3.1 \cdot 10^{8}$ & $3.4 \cdot 10^{8}$ & $3.4 \cdot 10^{8}$ & $9.0 \cdot 10^{8}$ & - & - \\
\hline 9 & $150 \pm 2$ & $70 \pm 2$ & $-/ /-$ & $3.3 \cdot 10^{8}$ & $1.9 \cdot 10^{8}$ & $3.4 \cdot 10^{8}$ & $8.8 \cdot 10^{8}$ & - & - \\
\hline
\end{tabular}

So, on the basis of the obtained research results, it is established that the drying temperature of mixtures of $130 \pm 2{ }^{\circ} \mathrm{C}$ at the inlet of the drying tower and $60 \pm 2{ }^{\circ} \mathrm{C}$ at the outlet is recommended both from the point of view of maintaining the viability of microorganisms and economically expedient. It should be noted that the $S$ thermophilus strain turned out to be the most resistant to elevated drying temperatures compared to E. faecium for all samples, regardless of the type of filler introduced.

The storage ability of dry products was studied for 18 months at a temperature of ( 6 $\pm 2)^{\circ} \mathrm{C}$ and a relative humidity of $80 \%$

The obtained research results are presented in Fig. 2 and Fig. 3.

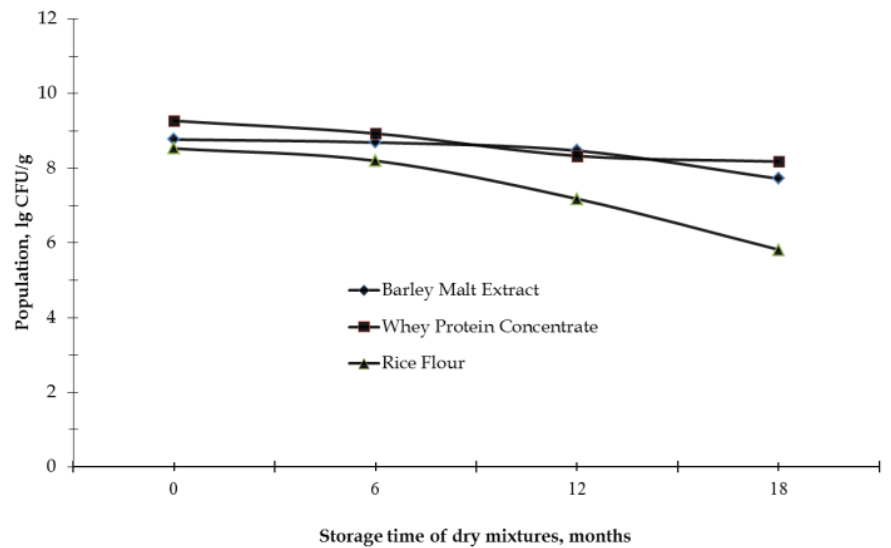

Figure 2 Content of viable cells of E. faecium in dry mixture during storage faecium by 2.1 times, compared with mixtures with rice flour, where the amount viable cells decreased 2.7 times and 2.9 times, respectively. Formulations with the addition of BME occupied an intermediate place: for mixtures with $S$. thermophilus, their number decreased 2.3 times, and for mixtures with E. faecium - 2.4 times (Table 2).

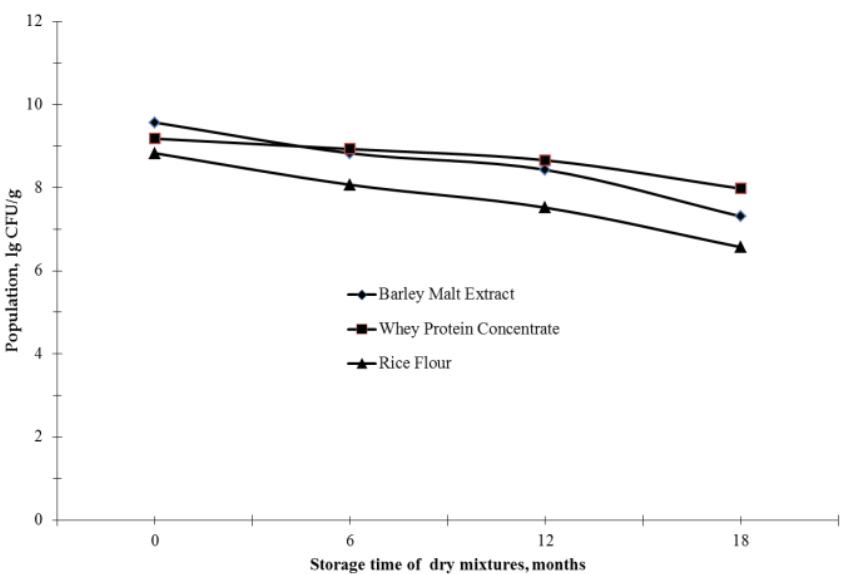

Figure 3 Content of viable cells of $S$. thermophilus in dry mixture during storage

It was found that during 18 months of storage, the number of viable cells of $E$. faecium (Fig. 2) decreased from the initial level by $11.8 \%$ in samples with WPC and by $11.9 \%$ in samples with BME, compared with formulations with rice flour where the specified parameter was $31.8 \%$. It should also be noted that in mixtures with WPC, the rate of viable cells was high both immediately after drying and during storage of the dry product during the indicated period. In contrast to the rather high stability in the number of microorganisms, such a pattern for activity during storage was not observed - it remained unchanged for only 3 months. During the said storage period, the content of viable cells of $S$. thermophilus (Fig 3 ) decreased from the initial level in the samples with WPC by $13.1 \%$, and in the test samples with BME and rice flour by $23.6 \%$ and $25.5 \%$, respectively. However, it should be noted that the samples with BME were more able to survive during drying; their content in the freshly made product was the highest, but during storage the values of the parameter decreased compared to the samples from WPC So, a high content of viable $E$. faecium cells during 18 months of storage was in the samples with WPC (the value of the parameter decreased by $11.8 \%$ ) and samples with BME (value of the parameter decreased by $11.9 \%$ ). For $S$ thermophilus, a high value was also inherent in the samples with WPC (the value of the parameter decreased by $13.1 \%$ ). A low number of viable cells of $E$. faecium and $S$. thermophilus was recorded for samples with rice flour both at the beginning of storage and during it.

\section{CONCLUSION}

The sensorial, physical and chemical characteristics of the mixtures were determined. It was found that an increase in the ammount of WPC from $1 \%$ to $6 \%$ 
lead to an increase in the protein content in the product from $25 \%$ to $37 \%$ compared to the control. At the same time, the values of the relative rate of dissolution increased by 2.7 times, and the values of active acidity decreased by 0.16 units. $\mathrm{pH}$ versus control.

It was established that the drying temperature of mixtures $130 \pm 2{ }^{\circ} \mathrm{C}$ at the inlet and $60 \pm 2{ }^{\circ} \mathrm{C}$ at the outlet are recommended both from the point of view of maintaining the viability of microorganisms and economic feasibility. It was noted that the Streptococcus thermophilus strain turned out to be the most resistant to elevated drying temperatures as compared to the Enterococcus faecium strain for all samples, regardless of the type of filler introduced. Strains of Lactobacillus acidophilus turned out to be least resistant to temperature, with an increase in drying temperature, their number decreased by 5.8 times.

As for the effect of the filler, it was found that the samples with Streptococcus thermophilus (the number of viable cells decreased by 1.7 times) and Enterococcus faecium (the number of viable cells decreased by 2.1 times) appeared to be the most resistant to temperature in the product with WPC.

The smallest losses of viable cells after 18 months of storage at a temperature of $(6 \pm 2)^{\circ} \mathrm{C}$ were for Enterococcus faecium and amounted to $11.8 \%$ and $11.9 \%$ for the experimental samples with the addition of WPC and BME. Despite losses during drying, thermophilic streptococci were fairly stable in storage. In particular, over 18 months of storage, the smallest losses (the value decreased by $13.1 \%$ ) were in the sample with the introduction of WPC, except for the samples with rice flour, which ensured the preservation of about $74.5 \%$ of the cells.

\section{REFERENCES}

Alekseeva, T. V., Kalgina, Yu. O., Razdobarina, N. V., Bokarev, D. A., Malakova, L. A. \& Evlakova, V. S. (2017). Expansion of the range of dairy products through the use of secondary resources. Storage and Processing of Farm Products, 10, 37 40 .

Burtsev, D. G. \& Cherobaev, V. N. (2010). Bifidogenous concentrate "Lactobel". Dairy Industry, 7, 42-43.

Chaudhary, R. C., Tran, D. V., \& Duffy, R. (2001). Speciality rices of the world: breeding, production and marketing. Food and Agriculture Organization of the United Nations (FAO).

Dobry, D. E., Settel, D. M., Baumann, J. M., Ray, R. J., Graham, L. J., \& Beyerick, R. A. (2009). A model-based methodology for spraydrying process development Journal of Pharmaceutical Innovation, 4(3), 133-142. https://dx.doi.org/10.1007/s12247-009-9064-4

Emam-Djomeh, Z. M, Yarmand, M. S. (2016). Optimization of spray drying conditions for production of ice cream mix powder flavored with black mulberry juice. Journal of Agricultural Science and Technology, 18, 1557-1570.

Food products. Methods of determination of lactic acid bacteria DSTU 7999:2015. (2016). Kyiv: State Enterprise Ukrainian Research and Training Center of Standardization, Certification and Quality.

Food products. Method for determination of yeast and mould: DSTU 8447:2015 (2016). Kyiv: State Enterprise Ukrainian Research and Training Center of Standardization, Certification and Quality.

Gabites, J. R., Abrahamson, J., \& Winchester, J. A. (2010). Air flow patterns in and industrial milk powder spray dryer. Chemical engineering research and design, 7, 899-910. https://doi.org/10.1016/j.cherd.2009.12.009

Gordienko, L. A., Yevdokimov, I. A. \& Zolotareva, M. S. (2008). Prospects of the use of whey protein concentrates in technologies of food products. Herald of North-Caucasus Technical University, 2(15), 66-70.

Ivanova, T. N. (2004). Merchandising and examination of grain and flour products Moscow: Publishing Center «Academia».

Ivkova, V. A. \& Piliaeva, A. S. (2011). Use of vegetable fats "Ecolact" in dry milk containing canned product for special purposes. Herald of Omsk State Agricultura University, 4, 55-58

Ivkova, V. A. \& Piliaeva, A. S. (2012a). Dry preserved milks for special purposes. Food Industry, 2012, 6, 64,65

Ivkova, V. A. \& Piliaeva, A. S. (2012b). Dry fermented milk product. Dairy Industry, 2010, 8, 83.

Kim, E. H., Chen, X. D., \& Pearce, D. (2002). Surface characterization of four industrial spray-dried dairy powders in relation to chemical composition, structure and wetting property. Colloids and Surfaces B: Biointerfaces. 26, $197-$ 212. https://doi.org/10.1016/S0927-7765(01)00334-4.

Klimenko, M. M. \& Avdieieva, L. Yu. (2001). Determination of the biological value of combined meat products with the addition of soya paste. Scientific Work of Ukrainian State University of Food Technologies, 10, 67-68.

Lipatov, N. N. (1978). Improving the production of dry milk products: collection of scientific papers of VNIMI. Issue 46. Moscow: Food industry.

Lishchenko, V. F. (2003). World resources of food protein. Food Ingredients. Raw Materials and Additives, 1, 12-15.

Lukianova, E. M, Samborskaya, E. P. \& Gutman, L. B. (Eds.). (1991). New products for dietary and therapeutic nutrition of pregnant women and children. Kiev: Naukova Dumka.

Lukin, A. A. \& Merenkova, S. P. (2016). Development of the bakery goods production technology using flour from germinated wheat grains. Bulletin of the South Ural State University. Series "Food and Biotechnologies", 4(3), 512. https://dx.doi.org/10.14529/food160301.

Mikhaleva, T. V., \& Popov, V. P. (2010). Particle motion during spray drying of milk. Dairy Industry, 4, 75-76.

Milk. Determination of nitrogen content. Part 2: Block-digestion method (Macro method): DSTU ISO 8968-2:2005 (IDF 20-2:2001) (ISO 8968-2:2001,IDT; IDF 20-2:2001, IDT). (2006). Kyiv: State Committee of Ukraine on Technical Regulation and Consumer Policy.

Milk and milk products. Methods of microbiological control: DSTU 7357:2013 (2014). Ministry of Economic Development and Trade of Ukraine.

Minorova, A. V., Romanchuk, I. O., \& Krushelnytska, N. L. (2013). Physical and chemical content of dry concentrates of whey proteins. Dairy Industry, 2, 32-33

Minorova, A. V., Romanchuk, I. O., Zhukova, Ya. F., Krushelnytska, N. L. \& Vezhlivtseva S. P. (2017). Protein composition and technological properties of milk whey concentrates. Agricultural Science and Practice. 4(2), 52-58. https://dx.doi.org/10.15407/agrisp4.02.052 .

Minorova, A. V., Romanchuk, I. O., \& Krushelnytska, N. L. (2018) Characteristics of dry milk-carbohydrate mixtures obtained by spray drying. Food Resources, 10, 206-212. https://doi.org/10.31073/foodresources2018-10-24.

Minorova, A. V., Rudakova, T. V., \& Krushelnytska, N. L. (2020). Biological value of dry milk multicomponent mixtures. Food Resources, 14, 125-136. https://doi.org/10.31073/foodresources2020-14-13

Molchanova, E. N. \& Suslianok, G. M. (2013). Quality evaluation and significance of food proteins. Storage and Processing of Farm Products, 1, 16-22.

Novokshanova, A. L., \& Ozhiganova, E. V. (2012). Food products for athletes Dairy Industry, 6, 82-83.

Ostroumova, T. L., \& Galstian, A. G. (2007). Technological properties of protein concentrates. Cheese Making and Butter Making, 2, 53-55.

Pritulska, N. V., Antyushko D.P., and Motuzka, Yu. M. (2012). Current trends in the sports nutrition market. Food Science and Technology, 1, 49-52.

Pritulska, N.,V., Karpenko, P. A., Gnitsevich, V. A., Fedorova, D. V., \& Yudina T. I. (2017). Scientific and practical aspects of the development of food products for military personnel. Scientific Works of the National University of Food Technologies, 5(2), 169-185. https://doi.org/10.24263/2225-2924-2017-23-5-2$\underline{23}$.

Rudavska, G. B., Tishchenko, E. V., \& Pritulska, N. V. (2002). Scientific approaches and practical aspects of optimizing the range of special-purpose products: monograph. Kyiv: Kyiv National University of Trade and Economics.

Rudavska, G., Khakhaleva, I. (2018). Antioxidant activity increasing of restored anti-stress action beverages. Goods and Markets, 2, 133-142. https://doi.org/10.31617/tr.knute.2018(26)13.

Schuck, P. (2002). Spray drying of dairy products: state of the art. Le Lait, 82(4), 375-382. https://dx.doi.org/10.1051/lait:2002017

Shamanova, G. P. (1993). Scientific substantiation and development of technology for dry dairy products for baby and dietary food, enriched with protective factors: $\mathrm{PhD}$ Thesis in Technique.

Tamim, A. J., \& Robinson, R. K. (2003). Yoghurt and analogue fermented dairy products: Scientific bases and technologies. St. Petersburg: Profession.

Vega, C, Goff, H.D., Roos, Y. H. (2005). Spray Drying of High-sucrose Dairy Emulsions: Feasibility and Physicochemical Properties. Journal of Food Science 70, 244-251. https://doi.org/10.1111/j.1365-2621.2005.tb07142.x

Vorobyova, V. M., Shatnyuk, L. N., Vorobieva, I. S., Mikheeva, G. A., Trushina, E. N., Zorina, E. E., \& Nikityuk, D. B. (2010). Classification and characteristics of specialized food products for athletes. Voprosy Pitaniia, 79(6), 64-68.

Wahlberg, M. (2010). Optimized spray drying. Danish dairy and food industry worldwide, 20, 32-33.

Yemelianova, S. O., Hrechko, N. Ya., Koshova, V. M., \& Sukhodol, V. Kh. (1994). Technology of malt extracts, concentrates of kvass wort and kvass. Kyiv: ISDO. 